\title{
Seorang penderita hipopituitarisme akibat kraniofaringioma
}

\author{
Ida Bagus Aditya Nugraha ${ }^{1}$, Made Arie Dwi Winarka ${ }^{1}$, A.A. Gd. Budhiarta ${ }^{2}$
}

1Program Studi Pendidikan Dokter Spesialis Penyakit Dalam, Fakultas Kedokteran Universitas Udayana/ RSUP Sanglah, Denpasar, Bali, Indonesia ${ }^{2}$ Departemen/KSM Penyakit Dalam, Fakultas Kedokteran Universitas Udayana/RSUP Sanglah, Denpasar, Bali Indonesia

Tanggal diterima : 22 Juni 2017 Tanggal Disetujui : 10 ktober 2017 Tanggal Diterbitkan : 15 Oktober 2017
Hipopituitarisme merupakan suatu kelainan di bidang endokrinologi yang ditandai dengan kurangnya sekresi baik secara total atau sebagian dari hormone pituitari anterior atau posterior atau keduanya. Kraniofaringioma merupakan tumor intrakranial tersering pada anak-anak dan merupakan tumor tersering pada region hipotalamus dan hipopituitari. Berikut ini akan dilaporkan satu kasus hipopituitarisme yang terjadi pada seorang penderita perempuan usia 15 tahun dengan kraniofaringioma yang juga telah dilakukan tindakan pembedahan.Diagnosis kraniofaringioma ditegakkan berdasarkan manifestasi klinis yaitu adanya gangguan pertumbuhan baik dari tinggi badan, pertubuhan tulang, rambut pada pubis, ketiak, atau ekstremitas, pasien tampak lemas, nafsu makan berkurang sedikit, dan saat kontrol pasien belum haid. Dari pemeriksaan MRI kepala + kontras menunjukan adanya massa di intersella sampai supra sella. Diagnosa hipopituitari didapatkan dari beberapa pemeriksaan hormonal yang terjadi. Penatalaksanaan yang telah dilakukan yaitu terapi pengganti hormonal GH, glukokortikoid, tiroksin, dan estradiol. Monitoring dilakukan tiap 3 bulan awal yang kemudian nantinya dapat diulang tiap 6 bulan.

Kata Kunci : hipopituarisme, kraniofaringioma, kasus jarang, Growth Hormone

Hypopituitarism is a disorder in endocrinology that's include decrease of partial or toal anterior pituitary hormone or posterior pituitary hormone or both. Craniofaringioma is an intracranial tumour that usually in children, located at hypothalamic and pituiray region. We reported a case report of hypopituarism in 15 years old female that caused by craniofaringioma and has been surgical. Diagnosis of craniofaringioma is confimed by the clinical manifestation are the disturbance of growth and development, in the height, bone, genital structure of hair, armpit hair, and extremity, decrease of apetite, weak, and no menstrual cycle until now. From the head MRI and contrast there are mass in interstellar unti supracelar. Hypopituary diagnosed is confimed from hormonal examination. The theraphy is the Growth Hormone substitusional theraphy, glucocorticoid, thyroxin, and estradiol. First we monitor every 3 months, and can repeat every 6 months.

Keywords : hypopituarism, craniofaringioma, rare case , Growth Hormone

\section{Pendahuluan}

Hipopituitarisme merupakan suatu kelainan di bidang endokrinologi yang ditandai dengan kurangnya sekresi baik secara total atau sebagian dari hormone pituitari anterior atau posterior atau keduanya. Terdapat beberapa etilogi yang dapat menyebabkan kondisi hipopituitarisme, dimana kondisi keganasan seperti adenoma pituitary atau terapinya sendiri (paska bedah dan/atau radioterapi) merupakan penyebab yang paling sering ditemukan. Kraniofaringioma sendiri merupakan tumor paraselar dan selar yang menjadi tumor intrakranial tersering pada anak-anak dan merupakan tumor tersering pada region hipotalamus dan hipopituitari. Tumor ini merupakan tumor jinak yang pertumbuhannya lambat dan paling sering terdapat pada sella tursika (lokasi hipofisis) dan sangat jarang pada nasofaring. ${ }^{1}$
Beberapa studi melaporkan angka prevalensi kejadian kelainan ini berkisar 45/100.000 dan insidennya terjadi 4/100.000/tahun, dimana rata-rata 50\% pasien memiliki defisiensi 3 hingga 5 hormon pituitari. Oleh karena itu, hipopituitarisme ini merupakan suatu kondisi medis yang sangat kompleks yang juga dikaitkan dengan tingginya angka mortalitas. $^{1}$

Beberapa faktor dapat mempengaruhi manifestasi klinis dari hipopituitarisme ini yaitu etiologi dari hipopituiarisme itu sendiri, usia penderita, dan kecepatan serta derajat kekurangan hormone pituitary yang terjadi. Suatu kondisi kekurangan hormone parsial biasanya memberikan progresifitas yang lambat sehingga sering tidak terdeteksi hingga bertahun-tahun, dan kemudian suatu waktu dapat terjadi kehilangan hormon secara total dengan tiba-tiba sehingga memerlukan kondisi emergensi yang membutuhkan 
penanganan segera. Manifestasi klinis hipopituitarisme sangat beragam, bergantung pada jenis hormone yang kurang tersekresi. Untuk itu penanganan hipopituitarisme ini juga sangat kompleks, meliputi terapi pengganti hormone tertentu bergantung pada jenis hormone yang kurang. ${ }^{1,2}$

Oleh karena jarangnya kasus hipopituitarisme ini disertai kompleknya pemeriksaan penunjang dan juga rencana terapi yang digunakan, maka berikut ini akan dilaporkan satu kasus hipopituitarisme yang terjadi pada seorang penderita kraniofaringioma yang juga telah dilakukan tindakan pembedahan.

\section{Ilustrasi Kasus}

Seorang perempuan usia 15 tahun kontrol ke poli endokrin RSUP Sanglah dengan keluhan pertumbuhan terhambat yang dialami sejak \pm 3 tahun lalu. Keluhan ini ditandai dengan tidak bertambahnya tinggi pasien dan juga belum mengalami menstruasi hingga saat ini. Keluhan ini juga disertai adanya gangguan penglihatan berupa kabur dan posisi bola mata kiri yang agak tertarik kearah kiri sehingga membuat pasien tidak nyaman. Pasien juga kadang sering merasa lemas dan kadang tidak antusias/bertenaga dalam aktifitas. Nafsu makan sedikit berkurang sehingga berat badan tidak pernah bertambah. Buang air kecil dikatakan tidak ada kelainan. Tidak ada riwayat sakit kepala ataupun muntah proyektil hebat sebelumnya. Pasien sebelumnya kontrol di rumah sakit daerah dengan pengobatan thyrax $100 \mathrm{mcg} /$ hari selama 6 bulan dan telah dilakukan beberapa pemeriksaan hingga didiagnosa adenoma hipofisis. Kemudian pasien kontrol ke RSUP sanglah dan dilakukan beberapa pemeriksaan, di antaranya MRI kepala dengan hasil massa hiperintens yang berbatas tegas dengan parenkim di sekitarnya di intersella sampai supra sella dengan ukuran $31 \mathrm{~mm}$ x $35 \mathrm{~mm}$ aksial, dan korona $30 \mathrm{~mm}$ x $49 \mathrm{~mm}$ (Gambar 1).
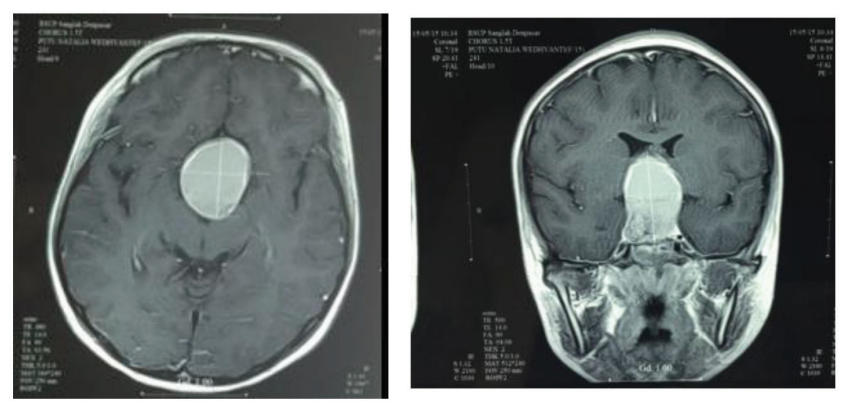

Gambar 1. MRI Kepala dengan kontras

Pasien kemudian dilakukan tindakan operasi dan biopsi jaringan massa dan didapatkan jaringan menyerupai adamantimoma tanpa ada sel-sel ganas, hingga disimpulkan suatu kraniofaringioma.
Setelah dilakukan tindakan operasi, pasien kemudian disarankan untuk kontrol ke poli endokrin untuk menilai fungsi hormonal paska operasi. Pada pemeriksaan fisik dijumpai penderita dengan kesadaran compos mentis, tekanan darah 120/80 mmHg, nadi $90 \mathrm{x} /$ menit kuat angkat, pernapasan $20 \mathrm{x} / \mathrm{menit}$, suhu aksila $36,5^{\circ} \mathrm{C}$. Status gizi cukup (berat badan $36 \mathrm{~kg}$ dengan tinggi badan 136,5 cm, Indeks Massa Tubuh: $19,46 \mathrm{~kg} / \mathrm{m}^{2}$ ). Tinggi badan kesan tidak sesuai dengan usia. Pada mata kiri tampak occuli sinistra retraksi, pertumbuhan rambut ketiak, pubis, kaki, dan tangan terhambat. (Gambar 2).

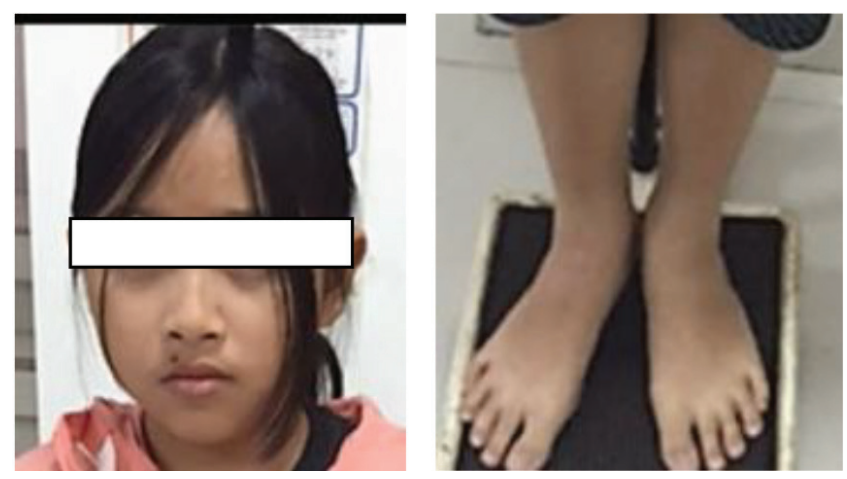

Gambar 2. Foto klinis pasien

Beberapa hormone diperiksa untuk memantau kinerja fungsi pituitari, yaitu Insulin Growth Factor-1 (IGF-1) $42 \mathrm{ng} /$ $\mathrm{ml}$ (normal: 226-903 ng/ml), hormone kortisol 1,48 $\mu \mathrm{g} / \mathrm{dl}$ (normal : 4,30 - 22,4 $\mu \mathrm{g} / \mathrm{dl}$ ), prolactin 3,00 ng/ml (normal 4,90-19,10 ng/ml) , Thyroid Stimulating Hormone (TSH) 0,06 $\mu \mathrm{IU} / \mathrm{ml}$ (normal: 0,25-5,00 $\mu \mathrm{IU} / \mathrm{ml}$ ), Free Tyroxine (FT4) 1,25 $\mathrm{ng} / \mathrm{dl}$ (normal 0,93-1,70 ng/dl), Luteinizing Hormone (LH) $<0,01 \mathrm{mIU} / \mathrm{ml}$ (normal 0,7-2,0 mIU/ml), Follicle Stimulating Hormone (FSH) 0,14 mIU/ml (normal 0,38-3,6 mIU/ml).

Secara keseluruhan dapat disimpulkan adanya penurunan beberapa hormon yang disekresikan oleh pituitari sehingga direncanakan pemberian terapi pengganti hormon. Sebelum diberikan terapi, perlu dilakukan foto usia tulang (bone age) untuk melihat masih terbukanya atau menutup epifisis dari tulang panjang. Pada foto radiologi tulang panjang didapatkan lempengan pertumbuhan epifisial masih terbuka, trabekulasi normal, celah dan permukaan sendi tampak normal, tak tampak pembengkakan jaringan lunak disekitarnya, dan disimpulkan bahwa foto tulang panjang tersebut sesuai untuk usia anak perempuan 9 tahun 6 bulan. Pasien juga dikonsulkan ke bagian obstetri ginekologi (obgin) untuk dievaluasi terkait hormon seksual.

Dari hasil evaluasi bagian obgin menyatakan bahwa pasien dengan keterlambatan pubertas dengan riwayat operasi kraniofaringioma dan pituitari dengan USG blast tersisi penuh, uterus dengan ukuran 4,22 x 1,78, disimpulkan dengan amenorea primer (Gambar 3). 


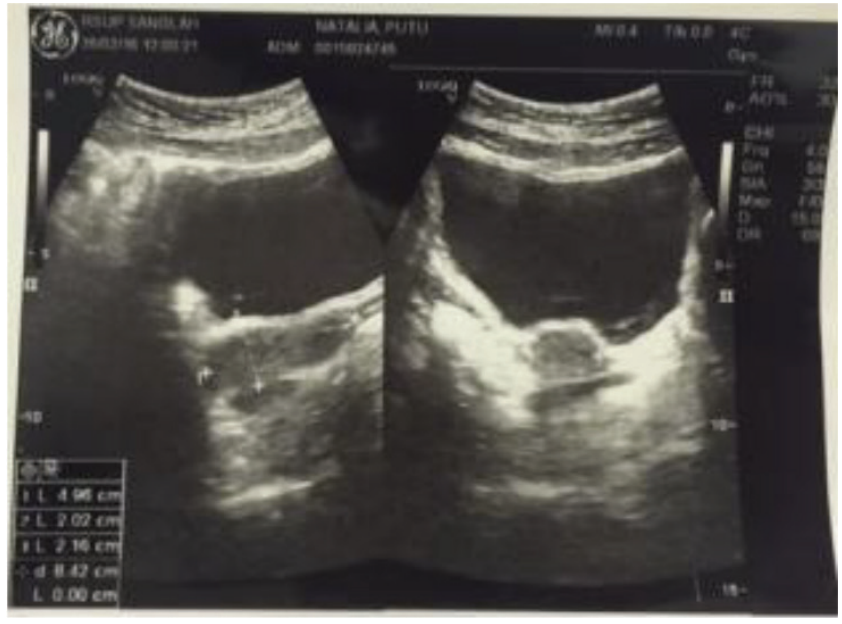

Gambar 3. Ultrasonografi (USG)

Berdasarkan anamnesis, pemeriksaan fisik, pemeriksaan penunjang dan hasil konsultasi dari bagian lain maka pasien didiagnosa dengan hipopituitarisme et causa kraniofaringioma + post op hipofisektomi disertai amenorea primer. Pada bulan Januari 2016, pasien ini mulai diterapi dengan hormon pengganti levotiroksin $100 \mathrm{mcg}$ io @ 24 jam, growth hormone (ginetrophin) 0,3 ml sc @ 24jam, cycloprogniova (estradiol) 2 mg io @24 jam, dan prednison 2,5 mg io@ 24 jam. Pasien ini kemudian di monitoring kembali tinggi badan, berat badan dan juga kadar hormonalnya (Tabel 1).

\section{Diskusi}

Kelenjar Hipofisis atau nama lainnya adalah kelenjar pituitari merupakan kelenjar yang berukuran sebesar kelereng, namun mempunyai makna fisiologis yang sangat penting bagi kelangsungan dan homeostasis tubuh manusia. Selain itu hipofisis, terutama bagian anterior, memiliki kemampuan dalam mengatur kelenjar-kelenjar endokrin lainnya. Hal inilah yang menyebabkan kelenjar ini diberi nama Master of Gland. Kelenjar hipofisis merupakan struktur kompleks pada dasar otak, terletak dalam sela tursika, di rongga dinding tulang sphenoid. kelenjar hipofisis manusia dewasa terdiri dari lobus posterior atau neurohipofisis sebagai lanjutan dari hipotalamus, dan lobus anterior atau adenohipofisis yang berhubungan dengan hipotalamus melalui tangkai hipofisis. Pada manusia lobus Intermedia terdapat menyatu dengan lobus anterior. ${ }^{1}$

Hipopituitarisme adalah suatu gambaran penyakit akibat insufisiensi kelenjar hipofisis, terutama bagian anterior. Gangguan ini menyebabkan munculnya masalah dan manifestasi klinis yang berkaitan dengan defisiensi hormonhormon yang dihasilkannya. Dari beberapa penyebab hipopituitarisme, adenoma pituitari atau terapi dari adenoma itu sendiri (pembedahan dan atau radioterapi) merupakan penyebab tersering hingga saat ini. Makroadenoma dengan ukuran > $1 \mathrm{~cm}$ dapat mengkompresi dan merusak secara langsung daerah di seikitar pituitari sehingga menyebabkan hiposekresi. Mekanisme lain disebutkan bahwa adanya massa pada pituitari dapat mengganggu sistem portal vaskular pituitari, meningkatkan tekanan intrasellar, sehingga terjadi nekrosis dan dalam jangka waktu lama akan mengganggu suplai sirkulasi portal dari pituitary.,3 Kraniofaringioma merupakan satu dari beberapa jenis massa penyebab tersering hipopituitari. Kejadian hipopituitari paska pembedahan dipengaruhi oleh ukuran tumor, tingkat invasi tumor ke jaringan sekitar, persentase bagian pituitari yang masih sehat, dan juga dipengaruhi oleh kemampuan tekhnik dokter bedah saraf. Dilaporkan sekitar 40-65\% pasien yang telah menjalani operasi akan mengalami perbaikan parsial kelenjar pituitari, akan tetapi kejadian perburukan paska operasi juga pernah dilaporkan. ${ }^{4}$ Pasien disarankan untuk melakukan monitoring pemeriksaan endokrin pre dan paska operasi.

Manifestasi klinis pasien hipopituitari dipengaruhi oleh patologi penyebab, derajat keparahan, dan kecepatan onset hipopituitari. Pada kondisi space occupying lesions

Tabel 1. Perkembangan kondisi pasien paska terapi hormonal

\begin{tabular}{lcccc}
\hline \multicolumn{1}{c}{ Pemeriksaan } & Januari 2016 & Maret 2016 & Mei 2016 & Normal \\
\hline TB $(\mathrm{cm})$ & 136,5 & 140 & 141 & \\
BB $(\mathrm{kg})$ & 36 & 38,5 & 41,5 & $(226-903)$ \\
IGF-1 $(\mathrm{ng} / \mathrm{ml})$ & 42 & 121 & 165 & $(0,25-5,00)$ \\
TSH $(\mu \mathrm{IU} / \mathrm{ml})$ & 0,06 & & 0,112 & $(0,93-1,70)$ \\
FT4 $(\mathrm{ng} / \mathrm{dl})$ & 1,25 & & 1,06 & $(4,30-22,4)$ \\
Kortisol $(\mu \mathrm{g} / \mathrm{dl})$ & 1,48 & & $<0,5$ & \\
\hline
\end{tabular}

Keterangan : TB= Tinggi Badan, BB= Berat Badan, IGF-1= Insulin Like Growth Factor 1, TSH= Thyroid Stimulating Hormone, FT4= Free Thryroxine. 
(sol), maka gejala yang dominan tampak adalah sakit kepala, gangguan penglihatan, dan yang sangat jarang ialah adanya perubahan kepribadian, epilepsi, hingga keluarnya cairan serebrospinal dari rinorea. Manifestasi sendiri bergantung pada jenis hormon mana yang mengalami defisiensi $1,5,6,7$

Kraniofaringioma tipe adamantinomatous adalah jenis yang umum terjadi pada anak anak. Terjadi perubahan pada sel epitel neoplastik berasal dari stomodeum yang terjebak pada duktus kraniofarimgeal saat perkembangan pituitari yang dikenal sebagai teori embriogenetik. Pada kraniofaringioma tipe ini sering terjadi defisiensi hormon pituitari akibat pendesakan tumr, prosedur pemebdahan dan radioterapi. pada awal diagnosis kita perlu mewaspadai terjadinya suatu disfungsi hormon pituitari sebesar 85\%. Defisiensi hormon pertumbuhan yang biasa terjadi adalah FSH dan $\mathrm{LH}^{12}$

Pada kasus, pasien dengan defisiensi GH ditandai dengan kurangnya semangat dalam aktifitas, terhambatnya pertumbuhan tulang dan otot, adanya defisiensi ACTH ditandai dengan lemas, nafsu makan berkurang sedikit sehingga berat badan tidak bertambah, tidak tumbuhnya rambut pada ketiak, pubis atau pada ekstremitas, defisiensi gonadotropin ditandai dengan adanya amenorea, dan adanya defisiensi TSH yang ditandai dengan lemas dan penurunan kadar hormon TSH.

Untuk mendiagnosa hipopituitarisme diperlukan pemeriksaan fisik yang baik, didukung pemeriksaan biokimia, dan mencari tahu penyebabnya. Pada pemeriksaan fisik dapat dilakukan pemeriksaan luas pandang dengan metode Goldmann. Pemeriksaan penunjang dilakukan untuk mengetahui kadar hormon dari pituitari anterior, seperti TSH, tiroksin, FSH,LH, prolaktin, IGF-1 dan kortisol jam 9 pagi. ${ }^{8,9,10}$

Untuk pemeriksaan defisiensi GH dilakukan pemeriksaan tes toleransi insulin (TTI) sebagai standar baku untuk penentuan defisiensi GH. TTI diindikasikan untuk pasien dewasa yang diduga kuat mengalami defisiensi berat terhadap GH. Tes ini dilakukan dengan cara injeksi insulin intravena 0,05-0,15 unit/kgbb (pasien sebelumnya puasa semalaman), kemudian diukur kadar glukosa dan GH pada 0,30,60,90,120 menit paska injeksi. Defisiensi GH bermakna apabila kadar puncak $\mathrm{GH} \leq 3 \mu \mathrm{g} / \mathrm{l}(9 \mathrm{mU} / \mathrm{l})$ dengan patokan nilai normal $5 \mu \mathrm{g} / \mathrm{l}$. TTI dikontraindikasi pada penyakit jantung iskemik, abnromal elektrokardiografi, aritmia, dan epilepsy. ${ }^{9}$

Tes lain yang dapat digunakan apabila terdapat kontraindikasi dilakukan TTI adalah kombinasi Growth Hormone Releasing Hormone (GHRH) + arginin, dan juga tes stimulasi glukagon. Beberapa kadar nilai potong yang tervalidasi untuk GHRH + arginin, dengan BMI $<25 \mathrm{~kg} / \mathrm{m}^{2}$ adalah $<11 \mu \mathrm{g} / \mathrm{L}$, BMI $25-30 \mathrm{~kg} / \mathrm{m}^{2}$ adalah $<8 \mu \mathrm{g} / \mathrm{L}$, BMI $>30 \mathrm{~kg} / \mathrm{m}^{2}$ adalah $<4 \mu \mathrm{g} / \mathrm{L}$. Keterbatasan sebagian besar pemeriksaan adalah kurangnya data relatif yang tervalidasi berdasarkan usia, jenis kelamin dan BMI. Pemeriksaan ini harus dilakukan pada unit endokrin berpengalaman yang mana tes tersebut sering dikerjakan.' Pemeriksaan lain yang dapat dilakukan untuk mendiagnosa defisiensi GH yaitu pemeriksaan kadar IGF-1, namun ada beberapa kondisi yang dapat membuat kadar IGF-1 rendah yaitu kondisi malnutrisi, penyakit hati, diabetes melitus, dan hipotiroidisme. ${ }^{2}$

Tes yang dapat dilakukan yaitu tes stimulasi ACTH dengan menggunakan injeksi synacten (agen kortikotropik) $250 \mu \mathrm{g}$ intramuskular. Pemeriksaan kadar kortisol dilakukan setelah 30 menit injeksi (paling baik pukul 9 pagi saat basal). Secara fisiologi, setelah dilakukan injeksi stimulasi ACTH, tubuh akan berespoon dan meningkatkan kadar kortisol darah. Pada kasus defisiensi ACTH, tubuh tidak akan berespon dan kadar kortisol darah $\leq 2 \mu \mathrm{g} / \mathrm{dl} .^{2,10}$

Defisiensi TSH ditandai dengan rendahnya kadar serum basal FT4 diikuti dengan kadar TSH yang normal atau rendah.

Pada beberapa kasus, untuk mendiagnosa defisiensi hipogonadisme cukup dengan test hormon basal dan evaluasi klinis. Pada perempuan, diagnosa ditegakkan bila kadar estradiol rendah dan LH serta FSH yang juga rendah disertai adanya oligomenorea atau amenorea. ${ }^{7}$

Diagnosis defisiensi hormon pituitari posterior dapat dengan mudah dilakukan melalui tanda dan gejala klinis serta dilakukannya tes deprivasi air. Secara klinis, adanya volume urine $>3 \mathrm{l} / \mathrm{hari}$ atau $40 \mathrm{ml} / \mathrm{kgbb} / \mathrm{hari}$ dapat dicurigai suatu defisiensi ADH. Tes deprivasi air dapat dilakukan dengan cara restriksi cairan selama 8 jam (pengawasan ketat status dehidrasi), apabila dalam 2 jam terjadi penurunan berat badan $>3 \%$ berat awal, maka tes harus dihentikan. Setelah 8 jam, diberikan injeksi intramuskular desmopressin $2 \mu \mathrm{g}$, kemudian 1 jam kemudian osmolalitas darah, urin, dan volume urin dihitung kembali. Apabila terjadi peningkatan osmolalitas urine dari $300 \mathrm{mOsmol} / \mathrm{kg}$ menjadi $>750 \mathrm{mOsmol} / \mathrm{kg}$ maka dapat dikatakan suatu defisiensi $\mathrm{ADH}$ atau kadang dikaitkan dengan diabetes insipidus kranial., ${ }^{2,10}$

Pada kasus, diagnosa ditegakkan berdasarkan anamnesis, pemeriksaan fisik, dan juga beberapa tes laboratorium kimia.Namun karena keterbatasan biaya serta tingginya resiko yang terjadi bila tes stimulasi dilakukan maka beberapa tes diagnosis tidak dilakukan.

Terapi pada hipopituitari terdiri dari terapi langsung penyebab dasar dan juga terapi pengganti hormonal. Tumor pituitari dapat diterapi dengan obat-obatan, pembedahan, radioterapi, atau kombinasi. Tujuan dari terapi pengganti hormonal adalah mencapai kadar hormonal yang normal, mengembalikan kondisi fisiologis, dan mencegah tanda dan gejala dari hipopituitarisme dan meminimalisir efek samping dari pengobatan. ${ }^{2,11}$ 
Pembedahan merupakan terapi utama pada kraniofaringioma. Berbagai studi preoperatif perlu dilakukan seperti pemeriksaan radiologi, evaluasi endokrin, evaluasi neuro-oftalmologi. Selain itu perlu dilakukan juga evaluasi neurobehavioral, dimana dilakukan terhadap aktivitas fisik, pengontrolannafsu makan, obesitas yang mana berkaitan dengan kerusakan hipotalamus. Tujuan utama dilakukan metode pembedahan pada kraniofaringioma adalah untuk mengontrol pertumbuhan tumor, pemeliharaan atau memperbaiki fungsi penglihatan, dan memelihara pituitari/ hipotalamus. Pendekatan pembedahan frontolateral merupakan prosedur yang paling umum dilakukan dalam sebuah serial kasus, yaitu pada 14 pasien (56\%). ${ }^{12}$

Pada kasus telah dilakukan tindakan pembedahan seperti yang dijelaskan pada referensi dan telah dilakukan evaluasi endokrin untuk melihat adanya kelainan pada hormon pituitari. Setelah dilakukan evaluasi laboratorium dilanjutkan dengan memberikan terapi pada hipopituitari terdiri dari terapi langsung penyebab dasar dan juga terapi pengganti hormonal. Tumor pituitari dapat diterapi dengan obat-obatan, pembedahan, radioterapi, atau kombinasi. Tujuan dari terapi pengganti hormonal adalah mencapai kadar hormonal yang normal, mengembalikan kondisi fisiologis, dan mencegah tanda dan gejala dari hipopituitarisme dan meminimalisir efek samping dari pengobatan. ${ }^{2,11,12}$

Untuk terapi GH dapat mulai diberikan dosis awal 0,2-0,3 mg injeksi subkutan dan dapat di titrasi naik tiap 4-6 minggu bergantung pada kadar IGF-1 dan respon klinis. Pemantauan komposisi tubuh dan kualitas hidup pasien dilakukan tiap 3 bulan, lalu bertahap tiap 6 bulan. Hal yang perlu dimonitoring meliputi berat badan, tekanan darah, IGF1 , gula puasa, $\mathrm{HbA} 1 \mathrm{c}$, profil lemak, rasio pinggang dan panggul, dan tiap 2 tahun dilakukan evaluasi terhadap densitas tulang. Efek samping yang perlu diperhatikan setelah terapi meliputi sakit kepala, atralgia, mialgia, retensi cairan, dan lain-lain. GH tidak boleh diberikan selama hamil dan juga masa menyusui. Tidak ada data bukti yang jelas mengenai penigkatan angka kejadian kembali tumbuh dan berkembangnya tumor pituitari/prepituitari pada pasien defisiensi GH yang sedang menjalani terapi hormon pengganti. Untuk itu disarankan untuk melakukan pemeriksaan radiologi sebelum dimulainya pemberian terapi GH. ${ }^{1,2}$

Pada defisiensi ACTH maka terapi pengganti glukokortikoid sangat diperlukan. Pada beberapa penelitian, hidrokortison lebih dipilih dikarenakan lebih fisiologis sebagai pengganti glukokortikoid seta efek sampingnya yang minimal dan dosis yang direkomendasikan yaitu dosis awal $10 \mathrm{mg}$, lalu saat makan siang $5 \mathrm{mg}$, dan saat pagi hari $5 \mathrm{mg}$. Apabila terjadi perubahan yang tidak signifikan, maka terapi dapat diberhentikan. Apabila terjadi perbaikan klinis, maka dosis dapat dinaikan 12,5 hingga $15 \mathrm{mg}$. Pemantaun juga perlu dilakukan terhadap kadar kortisol urin 24 jam. ${ }^{1,2}$

Pada defisiensi TSH, terapi utama adalah tiroksin, dimulai dengan dosis $100 \mu \mathrm{g}$ ( usia muda tanpa penyakit kardiak) atau $25 \mu \mathrm{g}$ (usia tua dengan penyakit jantung koroner). Tujuan terapi tiroksin adalah adanya perbaikan klinis disertai kadar FT4 yang normal. Pemberian obat ini dalam jangka waktu yang lama dapat meningkatkan kejadian atrial fibrilasi dan menurunkan densitas mineral tulang. ${ }^{1,2}$

Kondisi defisiensi goandotropin pada wanita dapat diberikan terapi pengganti estrogen (estradiol) dengan dosis 2-4 mg/hari. Apabila tidak tercapai perbaikan klinis selama pubertas, maka dosis estrogen dapat dinaikkan. Untuk wanita dengan uterus yang masih intak, terapi medroksiprogesteron (10 mg) dapat diberikan setelah 12-14 hari/ bulan terapi estrogen sangat dianjurkan. Terapi terus dilanjutkan hingga kondisi menopause untuk mencegah terjadinya osteoporosis dan dapat berefek sebagai anti aterosklerotik lipoprotein. Setelah kondisi menopause, dosis estrogen harus diturunkan secara bertahap lalu dihentikan., ${ }^{1,2,7}$

\section{Ringkasan}

Telah dilaporkan kasus hipopituitari akibat paska terapi pembedahan kraniofaringioma. Diagnosis ditegakkan berdasarkan manifestasi klinis yaitu adanya gangguan pertumbuhan baik dari tinggi badan, pertubuhan tulang, rambut pada pubis, ketiak, atau ekstremitas, pasien tampak lemas, nafsu makan berkurang sedikit, dan saat kontrol pasien belum haid. Dari pemeriksaan MRI kepala + kontras menunjukan adanya massa di intersella sampai supra sella. Diagnosa hipopituitari didapatkan dari beberapa pemeriksaan hormonal yang terjadi. Penatalaksanaan yang telah dilakukan yaitu terapi pengganti hormonal GH, glukokortikoid, tiroksin, dan estradiol. Monitoring dilakukan tiap 3 bulan awal yang kemudian nantinya dapat diulang tiap 6 bulan. Oleh karena adanya keterbatasan biaya dalam pemeriksaan, maka beberapa tes stimulasi tidak dilakukan begitu juga pada proses pemantauannya.

\section{Daftar Pustaka}

1. Prabhakar VKB, Shalet SM. Aetiology, Diagnosis, and Managament of Hypopituitarism an Adult Life. Postgrad Med J. 2006;82:259-66.

2. Seong YK. Diagnosis and Treatment of Hypopituitarism. Endocrinol Metab. 2015;30:443-55.

3. Zoicas F, Schofl C. Craniopharyngioma in Adults. Frontiers in Endocrionology. 2012;3(46):1-8.

4. Roijen, L van, Beckers A, Stevenaert A, Busschbach, Jan J van, Eijk, W van, Rutten FFH. The Burden of Hypopituitarism in Adults After Pituitary Surgery. Endocrinology and Metabolism. 1997;4(Suppl.B):139-42. 
5. Muller HL. Craniopharyngioma. Endocrine Reviews. 2014;35(3):513-43.

6. Halac I, Zimmerman D. Endocrine Manifestations of Craniopharyngioma. Childs Nerv Syst.2005;21:640-48.

7. Feldman EC, Nelson RW. Canine and Feline Endocrinology and reproduction, $3^{\text {rd }}$ ed. Philadelphia. WB Saunders.2003;305.

8. Filipsson H. Aspects of Diagnosis and Treatment of hypopituitarism in Adult Life. Thesis, University of Gothenburg, Swedan.

9. Cook DM, Yuen KCJ, Biller BMK, Kemp SF, Vance ML. American Association of Clinical Endocrinologist Medical Guidelines for Clinical Practice for Growth Hormone Use in Growth Hormone-Deficient Adults and Tranition Patients-2009 Update. Endocrine Practice. 2009;15(Suppl 2):1-29.
10. Jostel A, Lisset C, Shalet SM. Hypopituitarism. In: Endocrinology. New York. WB Saunders.pp 1-15.

11. Gan J. Is it Hypopituitarism?. Australian Pituitary Foundation LTD. 2011; pp:1-15.

12. Hidayat I, Susilo RI, Jasa ZK. Prosedur Operasi Kombinasi Frontolateral dan Pterional pada Kraniofaringioma di RSU dr. Zainoel Abidin Banda Aceh. JNI 2016;5(2): 13037.

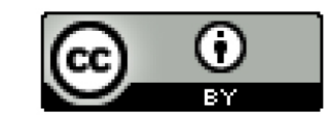

This work is licensed under a Creative Commons Attribution 4.0 International License. 